\title{
Gender as a Category of Analysis in Development and Environmental History SARA PURSLey
}

Middle Eastern and Islamic Studies, New York University, New York, N.Y.; e-mail: spursley@princeton.edu

doi:10.1017/S0020743816000490

In 2010, reflecting on her landmark 1986 article "Gender: A Useful Category of Historical Analysis," Joan Scott wondered whether, since the original article's publication, the category of gender had "lost its critical edge." 2 She noted how it had often come to refer simply to the roles assigned to "women" and "men," while those categories themselves were assumed to be determined by biological "sex" and thus stable and self-explanatory. In other words, the gender/sex binary persisted "despite a generation of scholarship aimed at deconstructing that opposition." ${ }^{3}$ Scott proposed that gender as an analytical category continues to be useful today only if it is "taken as an invitation to think critically about how the meanings of sexed bodies are produced in relation to one another, how these meanings are deployed and changed."

If, in Middle East studies, "gender" often gets used lazily today-sometimes simply as a synonym for "women"-it is also still used as a critical category of analysis. Indeed, for the past two decades gender studies has been one of the most dynamic and theoretically productive branches of the field. Here I would like to point to a problem that is related to the one Scott identifies and that seems to shape a certain division of scholarly labor, at least among historians. The use of gender as a critical category of analysis tends to be concerned with the study of discourse narrowly defined, or with what historians call "cultural history," while work dealing with the material world, with "real women" doing real work, tends to fall under "social history." The gender/sex opposition ends up aligning with equally problematic oppositions between discourse and the material world, representation and reality, culture and economy, even urban and rural space. Thus, many gender histories of the region have focused on urban, middle-class discourses in relation to European colonialism, nationalist movements, and state-building projects, while histories of economic development or agrarian life, when they deal with sexual difference at all, tend to treat "men" and "women" as selfevident categories. Critical gender history (as opposed to women's or family history) has hardly touched on the realm of the "economic," and it would seem to go without saying that gender as a critical category of analysis could not be relevant to something as material as environmental history.

In what may be a related phenomenon, most critical gender histories of the Middle East have dealt with the same time period: the late 19th century to the 1940s, or the high age of European colonialism in the region. There is little comparable work on the decades immediately following World War II, despite some fairly significant shifts during these years, including decolonization, the start of the Cold War, the rise of the United States as a superpower, the emergence of modernization theory, and, related to all of these, the dawn of the global "age of development." The result is that the use of gender as an analytical category has produced many insights into the workings of European colonial power, modernity, and formations of national identities in the region ${ }^{5}$ - but 
very few into the effects of American imperial expansion, for example, or those of the global postwar "development apparatus," which involved constructions and imaginaries of sexual difference extending far beyond urban, middle-class domains. ${ }^{6}$

In this essay, I ask what it might mean to bring gender history into conversation with both economic development and environmental history, in the context of an Iraqi land settlement project. $^{7}$ The Dujayla settlement was established by the Hashimite monarchy in 1945 as the pilot project for the broader Miri-Sirf Land Development (MSLD) program. The idea was to mitigate the effects of the country's agrarian crisis by relocating some of the rural landless poor onto state-owned lands that had been newly opened to agriculture through the building of large dams and irrigation systems. This, it was said, would have the stabilizing effect of producing a class of small "independent" or "family" farmers in Iraq, without alienating the country's large landowners through land confiscations.

By the early 1950s, Iraq's MSLD program had attracted the attention of many of the new US and international development organizations formed after World War II, including UNESCO, the UN's Food and Agriculture Organization, the US Point Four Program, and the World Bank. Planners in these agencies considered the program a perfect laboratory for demonstrating to a world increasingly riven by Cold War divisions the viability of the emerging US-led field of Western development expertise. A Point Four official effused that the Dujayla Law founding the pilot settlement, like "our own Homestead Act of pioneer days," would foster "the development of a class of small individual proprietors" and thereby "give Iraq the kind of progressive stability that the Middle East needs."

The whole project of designing, legislating, and producing "a class of small individual proprietors" is inconceivable outside of certain understandings about the relation of family structure and thus of sexual difference to agricultural production and political stability. But scholars of agrarian history in 20th-century Iraq, and elsewhere, have tended to uncritically accept and reproduce a familiar discursive slide in the sources, from the terms "independent farmer" to "individual farmer" to "family farmer," as if those modifiers were self-evidently interchangeable. Thus, the slide is allowed to obscure just what it should reveal: that a "dependent" male sharecropper or tribal nomad becomes a modern "independent" farmer not only through his acquisition of a new and truly individual title to land but also — and just as importantly — through his legally and socially constructed authority over a woman and children in an often newly defined "family."

The selection of Dujayla homesteaders from among the "fifty thousand land-hungry fellahin" who applied for the initial 1,200 tracts of land illustrates this logic. ${ }^{9}$ The government established a few criteria that helpfully eliminated 47,200 of the applicants from eligibility. These included the requirements that the would-be settler must be married; he must have at least one child; he must be over eighteen but under fifty years of age; and he must be free of criminal convictions and infectious diseases. ${ }^{10}$ These criteria established a baseline for what kind of human could conceivably count as an "individual" in the production of a class of individual farmers in Iraq, and left no doubt of the underlying, semi-implicit requirement, namely that he must be a "he." Yet in order to be eligible, this healthy and civil male candidate for individuality had to promise to settle on the land in the company of at least one woman and one child, and he had to be young to middle-aged himself - that is, an identifiable "head of household" in a 
nuclear family, regardless of his current status in what may have been an extended family household. Elders and other extended kin were not banned from Dujayla in the law; their presence was simply not legible in it. And if some were to happen along nonetheless-as in fact thousands would - their very illegibility would ensure their legal and economic powerlessness in the new relations of property, production, and family enacted by the legislators.

The settlement itself was designed on an isolated family-farm model, in which homesteads were built in clusters of four at the corners of the plots, each cluster one kilometer from the next. The "Four-Corners' Settlement Plan," it was hoped, would "save the settlers much time in going to and from their fields and avoid the unsanitary congestion of villages." 11 Indeed, villages were deliberately excluded from Dujayla. In addition to its purportedly positive effects on labor efficiency and hygiene, the isolated family-farm design-along with the deliberate policy of settling families from four different tribes in each of the four-farm clusters - was intended to reduce the political capacities of the settlers. ${ }^{12}$

UNESCO, the Food and Agriculture Organization, and Point Four all sent development missions of "home economics" experts to Iraq's MSLD settlements to retrain the women on the newly settled family farms. The original home economics project at Dujayla, which was run by UNESCO, sent teams of foreign and Iraqi female specialists into settlers' homes to teach women modern principles of health care, hygiene, childraising, gardening, nutrition, and household budgeting. The project ended up focusing primarily on health and hygiene, however, apparently because these were the only aspects of the program that Dujayla women seemed to have any interest in. ${ }^{13}$ This interest was fueled by the fact that the settlement plan had turned out to be counterproductive to achieving one of the aims most often invoked in its defense: improved sanitation and hygiene. The isolation of the homesteads from one another precluded the piping of clean water into them or even the use of a shared well for drinking water, fostering the spread of disease among settlers forced to use the same canals for their irrigation, drinking, and sewage needs.

Thus, while home economics experts worked to overcome the ignorance of rural housewives, which was purportedly responsible for the high rate of disease at Dujayla, the settlement plan itself-which privileged the creation of isolated nuclear-family farms over all other development considerations-guaranteed that the settlers would have no access to a clean water source. In the perpetual return to "ignorance" as the explanation for diseased rural bodies, neither the historicity of rural lives nor that of their environment (houses, canals, soil, microbes, etc.) was truly legible, even when it was explicitly recognized. ${ }^{14}$ When the foreign workers arrived at Dujayla, what they found were the very problems they had been trained to solve: "Three out of four suffered from bilharzia, a debilitating water-borne disease characterized by slow bleeding, and other diseases were also rife. This was where the team had to start; out of health activities would come not only confidence in the team but an interest in clean water, clean bodies, better homes and food, even reading and writing." 15 The temporal narrative of development required that the experts start at what for them was the beginning: rural ignorance of modern health and hygiene principles. This, in turn, predisposed them to forget, again and again, that the settlers' lives, habits, and bodies were powerfully shaped and in important ways determined by the settlement itself. 
One of the more fruitful directions in the scholarship criticizing postwar development projects has been to explore how development problems were "rendered technical," and to criticize the depoliticizing moves of this strategy. ${ }^{16}$ While such work has yielded important insights, my research calls into question certain aspects of the "rendering technical" argument as it is often framed, and points to the relevance of gender as an analytical category in histories of development. Despite all the formidable structural obstacles to health and hygiene that development workers at Dujayla couldn't help but notice, what they found to be the ultimate cause of the many diseased bodies on the settlement was not political, environmental, or technical conditions but local human ignorance and underdevelopment, especially of women. The production of "independent" farmers meant the production of farmers with healthy bodies and citizenly sensibilities who would neither flee to the cities nor be dependent on the government for assistance, much less look toward larger political or socioeconomic reform. And an "independent" farmer was by definition a "family" farmer in part because he had a wife, who could be mobilized to cultivate the family's economic and bodily nondependence. After all, "healthy bodies would not need extra feeding at school nor would they be prone to be tubercular." 17 Development problems at Dujayla were indeed rendered technical, in the sense that they were rendered amenable to the interventions of specialists applying new knowledge techniques. But an examination of the most strongly prioritized techniques, in both theory and practice, shows how they were also rendered social, and in particular how they were rendered feminine.

The Dujayla laws and settlement plan had worked to constitute a new kind of Iraqi citizen, the "independent" or "family" farmer, and they did so by embedding him in legal, social, and spatial grids that depended on and produced other human kinds, including housewives, children, extended-family kin, and seasonal wage-laborers. ${ }^{18}$ As the legal property grid of the nuclear-family farm became the spatial grid of the four-corners settlement plan, into which humans were inserted, it was hoped that new forms of dependence and independence, and new relationships between people and the things around them, would be enabled. The application of these grids was part of a larger modernizing project in Iraq that involved the production and fixing of space-including stabilizing the course and flow of the two great rivers, expanding the area of cultivable land, settling nomads and their herds of animals, and introducing intensive methods of agriculture on small, fixed-size plots. That is, setting the nation into dynamic temporal motion toward a developed future was seen to depend on the construction of new kinds of spatial immobilities, especially for peasants, nomads, women, and the rural nonhuman world.

As it happened at Dujayla, the outcome of these efforts to fix land, water, humans, animals, and plants in certain spatial grids was social and ecological catastrophe. Not only did the isolated family-farm design foster the spread of human disease on the settlement, but the intensive agricultural methods on which the small farms depended-and the lack of infrastructure to sustain such methods (especially a drainage system) —led to the rapid salinization of the soil. Within two decades, most settlers had abandoned their plots and use of the land had "reverted to the original extensive form of sheep husbandry."19 But the collapse of the Dujayla project does not exactly signify the ineffectiveness of the techniques for which its inhabitants served as a laboratory. Among its lasting effects were the reconstitution of several thousand rural lives and an expansion of technocratic expertise in 
both Iraq and the emerging international body of development organizations that identified the family — and women in particular — as a primary locus of development programs.

Over the past few decades, many scholars of agrarian family history in various regions of the world have agreed that the narrative of the "rise of the nuclear/conjugal family" is of little relevance to their work. In a classic critique along these lines, Joan Smith and Immanuel Wallerstein objected to the claim that "the family was previously large and 'extended' but today (or in modern times) it has been getting smaller and more 'nuclear.' . . . This image of the family, as perpetrated by world social-science, has been an obstacle to our understanding of how households have in fact been constructed in the capitalist world-economy." " In this essay, I have suggested that the rise of the nuclear family narrative is much more than an image "perpetrated by world socialscience," in part because world social science does not stand outside the reality it claims to describe, and thus cannot be simply isolated and pushed aside as an "obstacle to our understanding" of that reality. The nuclear/conjugal family type, with the particular forms of sexual difference it constructs, need not be understood simply as the telos of a universal historical process, the empirical realization of which historians would then set out to prove or disprove in this or that location. It can instead be seen as a conceptual, legal, and spatial grid that makes certain kinds of "family" relationships legible so they can be worked on by technologies of governmentality and development, while simultaneously making other relationships illegible, even when they continue to exist or emerge for the first time.

Attending to the centrality of the nuclear/conjugal family model in at least some postwar development projects-where its effects were not only discursive but also radically transformative of rural environments, experiences, and bodies-thus shifts the terms of the longstanding scholarly debate over the relevance of that model in rural areas outside the industrialized West. At Dujayla, the nuclear-family grid had limited success in unraveling extended family bonds or in producing recognizably bourgeois familial sentiments among rural Iraqis - nor, in the end, did it help fuel the capitalist development of agriculture in Iraq. But it nevertheless played a powerful role in the remaking of both time and space for those whose lives had become enmeshed in a development apparatus, while providing state officials and development planners with an identifiable point of entry - the rural housewife—for projects of reform and improvement.

\section{NOTES}

${ }^{1}$ Joan W. Scott, "Gender: A Useful Category of Historical Analysis," American Historical Review 91 (1986): 1053-75.

${ }^{2}$ Joan Wallach Scott, "Gender: Still a Useful Category of Analysis?,” Diogenes 225 (2010): 10.

${ }^{3}$ Ibid., 11.

${ }^{4}$ Ibid., 10 .

${ }^{5}$ See, among many others, Wilson Chacko Jacob, Working Out Egypt: Effendi Masculinity and Subject Formation in Colonial Modernity, 1870-1940 (Durham, N.C.: Duke University Press, 2011); Beth Baron, Egypt as a Woman: Nationalism, Gender, and Politics (Berkeley, Calif.: University of California Press, 2005); Lisa Pollard, Nurturing the Nation: The Family Politics of Modernizing, Colonizing, and Liberating Egypt, 1805-1923 (Berkeley, Calif.: University of California Press, 2005); Afsaneh Najmabadi, Women with Mustaches and Men without Beards: Gender and Sexual Anxieties of Iranian Modernity (Berkeley, Calif.: University of California Press, 2005); Ellen Fleischmann, The Nation and Its "New" Women: The Palestinian Women's Movement 1920-1948 (Berkeley, Calif.: University of California Press, 2003); Elizabeth Thompson, 
Colonial Citizens: Republican Rights, Paternal Privilege, and Gender in French Syria and Lebanon (New York: Columbia University Press, 2000).

${ }^{6}$ The term "development apparatus" is from James Ferguson, The Anti-Politics Machine: "Development," Depoliticization, and Bureaucratic Power in Lesotho (Minneapolis, Minn.: University of Minnesota Press, 1994).

${ }^{7}$ The argument and research presented here are drawn from my book manuscript, Familiar Futures: Time, Selfhood, and Sovereignty in Iraq, 1920-63 (Stanford, Calif.: Stanford University Press, in contract).

${ }^{8}$ Norman Burns, "Development Projects in Iraq: I. The Dujaylah Land Settlement," Middle East Journal 5 (1951): 362-63.

${ }^{9}$ Ibid., 363.

${ }^{10}$ See Warren Edward Adams, "The Land Development Program in Iraq with Special Reference to the Dujaila Settlement, 1945 to 1954" (PhD diss., University of California, Berkeley, 1955), 302; Burns, "The Dujaylah Land Settlement."

${ }^{11}$ Burns, "The Dujaylah Land Settlement," 364.

${ }^{12}$ H.J. Rousseau, "Fundamental Education in Primary Teachers Colleges in Iraq: Suggested Programme," n.d., File: Rousseau H. J., Box: Iraq CPx/REP.3/258, UNESCO Archives, Paris; Brad Fisk, "Iraq's Pilot Project for Land Settlement," Economic Geography 28 (1952): 343-54.

13“Ma Ya'mal al-Nisa” fi al-Dujayla," al-Mu'allim al-Jadid 18 (1955): 62-64.

${ }^{14}$ For example, see A.B. Trowbridge, "Report for Sept, Oct, and November, 1952," 1 December 1952, File: Dujailah/Trowbridge A. B., Box: Iraq CPx/REP.3/259, UNESCO Archives, Paris.

${ }^{15}$ UNESCO correspondent in Dujayla, "UNESCO Team at Work," Times Educational Supplement, 1 May 1953. Emphasis added.

${ }^{16}$ For example, Ferguson, The Anti-Politics Machine; Arturo Escobar, Encountering Development: The Making and Unmaking of the Third World (Princeton, N.J.: Princeton University Press, 1995).

${ }^{17}$ A. B. Trowbridge, "The Aim of the Unesco Fundamental Education Mission in Iraq," 20 October 1954, 1, File: Dujailah/Trowbridge A. B., Box: Iraq CPx/REP.3/259, UNESCO Archives, Paris.

${ }^{18}$ See Ian Hacking, "The Looping Effects of Human Kinds," in Causal Cognition, ed. D. Sperber and A. J. Premack (Oxford: Oxford University Press, 1996).

${ }^{19}$ Kamil Mahdi, State and Agriculture in Iraq: Modern Development, Stagnation and the Impact of Oil (Reading, UK: Ithaca Press, 2000), 168.

${ }^{20}$ Joan Smith and Immanuel Wallerstein, "Households as an Institution of the World-Economy," in Creating and Transforming Households: The Constraints of the World-Economy, ed. Joan Smith and Immanuel Wallerstein (Cambridge: Cambridge University Press, 1992), 4. 